\title{
ANALISIS PENGARUH JOB DEMAND TERHADAP WORK ENGAGEMENT MELALUI BURNOUT
}

\author{
Barrotul Jazilah \\ Universitas Negeri Surabaya \\ jazilahb@gmail.com
}

Abstract

\begin{abstract}
The aim of this research was to explore burnout, work engagement, and job demand among debt collector workers. The total available population of employees $(N=32)$ Consumer Collection and Remedial Unit Bank Tabungan Negara Cabang Surabaya participated in this study. Utrecht Work Engagement Scale, Maslach Burnout Inventory and Job demand scale were used as measuring instruments. Partial Least Square (PLS) and supported by SmartPLS 3.0 software were used as a statistical analysis. The result showed that job demand has significant positive effect on work engagement and burnout. On the contrary, burnout has no significant effect on work engagement and cannot mediated the effect of job demand on work engagement. Improved job resources and managing challenge demands are offered as recommendations to improve employee engagement.
\end{abstract}

Keywords: burnout; challenge demands; job demand; job resources; work engagement.

\section{PENDAHULUAN}

Revolusi industri 4.0 merupakan era otomatisasi proses operasional perusahaan ke tingkat yang baru dengan memperkenalkan teknologi produksi masal yang dapat disesuaikan dan fleksibel, dengan kata lain proses operasional perusahaan dapat berkomunikasi dengan teknologi tidak sekedar mengoperasikan teknologi (Martin, 2017). Oleh karena itu, perusahaan perlu menyelenggarakan pengembangan human capital sesuai kebutuhan perubahan agar mampu bersaing dan menunjang tercapainya tujuan dan kesuksesan perusahaan (Cahyani, 2019).

Fazlurrahman (2018) menjelaskan perusahaan yang tidak membuat perubahan dan merasa nyaman dengan keadaan yang apa adanya akan mengakibatkan pertumbuhan perusahaan menjadi stagnant dan menjadi awal dari kehancuran suatu perusahaan. Tuntutan perubahan industri 4.0 berimbas pula pada industri perbankan dan keuangan. Perbankan merupakan salah satu sektor vital negara karena digunakan oleh pemerintah sebagai alat kebijakan moneter untuk mendorong pertumbuhan ekonomi nasional. Perbankan yang menjadi Badan Usaha Milik Negara (BUMN) dengan fokus utama menyediakan pembiayaan perumahan dan apartemen salah satunya adalah Bank Tabungan Negara (BTN). Consumer Collection and Remedial Unit (CCRU) merupakan unit khusus yang bertugas memberikan pembinaan dan melakukan penagihan kepada debitur yang mengambil pinjaman perumahan atau apartemen, maka dari itu unit ini berperan penting dalam menjaga kelangsungan laba bunga Bank Tabungan Negara.

Berdasarkan wawancara dengan pimpinan Consumer Collection and Remedial Uni bahwa pada tahun 2014 Consumer Collection and Remedial Unit Bank Tabungan Negara Cabang Surabaya meraih penghargaan atas "Pencapaian Target Kualitas Kredit" dan sejak itu mendapat julukan sebagai "Bintangnya BTN". Namun, pada tahun 2019 julukan tersebut dicabut oleh branch manager Bank Tabungan Negara Cabang Surabaya karena dianggap tidak mampu memenuhi target yang telah diberikan yang menjadi tolok ukur kinerja debt collector. Hal tersebut menunjukkan bahwa work engagement diperlukan karyawan agar dapat mengatasi tantangan dan hambatan pekerjaan serta mencapai tujuan organisasi.

Schaufeli et al. (2013) menjabarkan work engagement (keterlibatan kerja) sebagai perpaduan dari tiga konsep yaitu kepuasan kerja, komitmen terhadap organisasi, dan perilaku ekstra yaitu upaya diskresioner yang melampaui tugas dari pekerjaan sendiri. Sementara itu, Bakker \& Demerouti (2016) memaknai work engagement sebagai kondisi mental karyawan ditandai oleh energi fisik yang penuh, sikap antusias terhadap pekerjaan, dan karyawan merasa seakan-akan tenggelam di dalam pekerjaan mereka. Bakker et al. (2014) menyatakan optimalisasi job demand dapat mendorong work 
engagement meningkat. Optimalisasi job demand dapat dilakukan dengan cara mengurangi ambiguitas peran, pengelolaan konflik dan meningkatkan jaminan masa depan pekerjaan.

Job demand diindikasikan sebagai suatu aspek pekerjaan yang meliputi fisik, psikologis, sosiologis serta organisasional di mana membutuhkan upaya baik fisik ataupun psikologis serta segala sesuatu yang berkaitan dengan biaya psikologis maupun fisiologis (Lee et al., 2019). Job demand dapat diklasifikasikan berdasarkan bidang pekerjaan, sebagaimana tuntutan pekerjaan fisik lebih relevan untuk karyawan dengan pekerjaan seperti kontraktor dan binaragawan, sementara tuntutan kognitif cenderung pada profesi seperti ilmuwan dan produser (Bakker et al., 2014).

Penelitian terdahulu Nahrgang et al. (2011) membuktikan job demand dapat berpengaruh signifikan negatif ke work engagement. Penelitian Upadyaya et al. (2016) memperkuat efek yang signifikan negatif job demand pada work engagement. Sementara itu, Ramadhani \& Hadi (2018) menjelaskan bahwa job demand tidak dapat memengaruhi work engagement karyawan bagian akuntan kantor PT. $\mathrm{X}$ wilayah Jombang.

Fenomena overload dan ambiguitas peran ditemukan pada karyawan Consumer Collection and Remedial Unit sebagaimana penjelasan dari karyawan bagian administrasi bahwa karyawan turut mengerjakan tugas yang tidak masuk dalam job desk karyawan seperti mengurus berkas lelang dan iklan koran yang seharusnya menjadi tugas unit pelelangan. Sementara itu, karyawan bagian collective menuturkan posisi assistant collective yang kosong menyebabkan tugas dan beban kerja yang dimiliki karyawan bagian collective lebih banyak sehingga hasil pekerjaan kurang maksimal. Broeck et al. (2017) menyatakan apabila pengelolaan tuntutan pekerjaan kurang baik maka dapat berkembang menjadi faktor-faktor penyebab burnout.

Burnout merupakan kelelahan ekstrim akibat dari kelelahan yang berkepanjangan, penggunaan fisik yang intens, afektif dan kelelahan kognitif yang disebabkan oleh paparan kondisi kerja tertentu dalam waktu yang lama (Bakker et al., 2004). Menurut Nahrgang et al. (2011) burnout dapat tercermin dari rendahnya kesejahteraan karyawan yang mencakup gangguan kecemasan, depresi serta stress terkait pekerjaan.

Penelitian Oktarina (2017) menunjukkan job demand memiliki pengaruh signifikan positif pada burnout di PT Kusuma Putra Santosa Karanganyar. Kim \& Wang (2018) memperkuat bahwa job demand berpengaruh signifikan positif terhadap burnout pada karyawan pelayanan publik. Salmelaaro \& Upadyaya (2018) menambahkan job demand signifikan positif dapat memengaruhi burnout pada karyawan swasta di Finlandia.

Berdasarkan wawancara dengan karyawan assistant field collector menuturkan dalam bertugas di lapangan mengunjungi debitur, karyawan bisa beradu pendapat dengan debitur, sehingga menyebabkan perasaan gelisah dan dibawa oleh karyawan sampai di rumah. Adu pendapat dengan debitur juga seringkali dialami oleh karyawan bagian desk call yang bertugas melakukan penagihan serta pembinaan melalui telepon dan personal chat menyebabkan suasana hati yang buruk dan gelisah setiap akan memasuki ruangan kantor karena ditambah beban target bulanan yang harus dicapai.

Hasil pengamatan ditemukan karyawan bagian desk call staff lebih sensitif atau mudah marah saat bekerja karena mereka juga harus mengerjakan pekerjaan rekan kerja lain yang berkaitan dengan pemberkasan di kantor. Karyawan bagian administrasi seringkali mendapat masalah dan teguran dari para atasan karena mengerjakan tugas rekan kerja lain yang tidak ia kuasai sehingga hasilnya kurang maksimal. Karyawan seringkali mengeluhkan jam pulang kerja yang tidak menentu dan lembur yang hampir setiap hari. Kondisi-kondisi kerja tersebut menyebabkan karyawan lebih mudah sakit sebagaimana pendapat dari salah satu karyawan bagian desk call yang telah 8 tahun bekerja. Bakker et al. (2014) menjelaskan bahwa burnout sangat kuat dapat memengaruhi health-related outcomes dan job-related outcomes, oleh karena itu upaya menurunkan burnout diperlukan agar karyawan dapat memaksimalkan kontribusi positif kepada perusahaan. 
Villavicencio-ayub et al. (2015) membuktikan bahwa burnout signifikan memengaruhi work engagement. Moeller et al. (2017) menjelaskan bahwa burnout berkorelasi negatif dengan work engagement pada karyawan di Amerika Serikat. Searah dengan penelitian sebelumnya, Broeck et al. (2017) bertujuan untuk memvalidasi Job Demand Resources Model lintas sektor bisnis menemukan bahwa burnout dengan work engagement memiliki hubungan yang negatif pada karyawan dari berbagai sektor di Belgia.

Penelitian ini bertujuan untuk mengeksplorasi dan menganalisis dampak job demand terhadap work engagement melalui burnout pada karyawan Consumer Collection and Remedial Unit Bank Tabungan Negara Cabang Surabaya.

\section{KAJIAN PUSTAKA DAN PENGEMBANGAN HIPOTESIS}

\section{Teori Job Demand}

Yener \& Coskun (2013) menerangkan job demand yaitu serangkaian tuntutan pekerjaan utama karyawan meliputi ambiguitas peran, konflik peran, stress, tekanan pekerjaan dan pekerjaan yang tidak tuntas. Bakker \& Demerouti (2016) membedakan job demand menjadi dua yaitu hindrance demands dan challenge demands. Hindramce demands mengacu pada gangguan atau kendala yang dapat menghambat individu dalam rangka mencapai tujuan, contohnya konflik peran dan ambiguitas peran. Challenge demands diartikan sebagai tuntutan pekerjaan yang berpotensi meningkatkan pertumbuhan personal dan prestasi pribadi karyawan, contohnya time pressure dan tanggung jawab.

Menurut Coetzer \& Rothmann (2007), meskipun job demand tidak mengacu pada hal negatif, namun apabila terdapat tuntutan usaha dan biaya yang lebih tinggi maka dapat menyebabkan respon seperti depresi, kecemasan dan kelelahan. Schaufeli \& Bakker (2004) menemukan bahwa job demand dapat menyebakan burnout, sehingga dapat berdampak pula pada work engagement karyawan.

Hurrel et al. (1988) menerangkan empat faktor penyebab job demand yaitu agenda pekerjaan, intensitas pekerjaan, job control, serta beban \& ruang kerja. Bakker et al. (2004) menjelaskan terdapat tiga indikator job demand yaitu workload, emotional demand dan work-home conflict. Sementara itu, Yener \& Coskun (2013) mengungkapkan tiga indikator sebagai pengukur job demand yaitu role ambiguity, role conflict dan work overload.

\section{Teori Burnout}

Kristensen et al. (2005) mendefinisikan burnout sebagai kelelahan yang terdiri dari kelelahan fisik, kelelahan emosional, kelelahan kognitif serta kelelahan yang diakibatkan klien. Maslach \& Leiter (2016) memaknai burnout sebagai suatu psychology sindrome sebagai akibat kelelahan secara emosional, depersonalisasi dan juga menurunya prestasi pribadi yang dapat dialami diantara individu dalam kapasitas tertentu bekerja bersama orang lain.

Montgomery et al. (2015) berpendapat bahwa saat seseorang mengalami burnout maka mereka akan merasa lelah secara emosional, memiliki sedikit energi untuk berinvestasi pada pekerjaan seperti dulu, mereka mengalami depersonalisasi yang dimaknai sikap sinis pada segala sesuatu yang berkaitan dengan pekerjaan, mereka juga mengalami perasaan gagal dalam segala hal terkait pekerjaan.

Terdapat enam kunci utama pendorong terjadinya burnout menurut Maslach \& Leiter (2016) diantaranya beban kerja yang terlalu tinggi, kurangnya kontrol karyawan terhadap pekerjaan, kurangnya penghargaan atau pengakuan, minim dukungan dari rekan kerja atau orang-orang di lingkungan kerja, ketidakadilan, dan kesenjangan antara individu dengan nilai-nilai organisasi. Maslach \& Leiter (2016) menjelaskan tiga indikator yang dapat digunakan untuk mengukur burnout yaitu exhaustion, cynism dan inefficacy.

\section{Teori Work Engagement}

Merujuk Bakker et al. (2014) memberikan keterangan work engagement sebagai suatu perilaku energik (vigor), emosional (dedication) dan komponen kognitif (absorption). Vigor dicerminkan saat 
bekerja memiliki ketahanan mental yang kuat dan energi yang tinggi, memiliki kemauan berusaha serta berupaya dalam suatu pekerjaan, dan juga tekun meskipun menghadapi hambatan. Dedication dapat dilihat dari adanya keterlibatan seseorang di dalam pekerjaan dan mendapati kebermaknaan, antusiasme serta tantangan. Absorption ditandai konsentrasi yang penuh serta asyik dalam pekerjaan. Work engagement juga dapat diartikan sebagai adanya pemenuhan yang dapat menghindarkan seseorang mengalami kehampaan sehingga menciptakan perasaan serta jiwa yang kosong dalam diri seseorang seperti kehabisan tenaga (Bakker et al., 2014).

Nahrgang et al. (2011) memiliki penjelasan tentang work engagement yang mewakili tingkat keterlibatan, partisipasi dan komunikasi karyawan dalam kegiatan yang berhubungan dengan keselamatan dan kepatuhan atau sejauh mana karyawan tunduk terhadap aturan dan prosedur keselamatan. Cole et al. (2012) menambahkan makna dari work engagement itu relatif terhadap konstruksi yang ada seperti kepuasan kerja, komitmen organisasi dan keterlibatan dalam pekerjaan.

Perrin (2013) menyatakan terdapat sepuluh faktor pendorong work engagement yaitu management senior yang memperhatikan karyawan, suatu pekerjaan menantang, memperoleh suatu wewenang untuk mengambil keputusan, perusahaan yang berorientasi kepuasan pelanggan, kesempatan jenjang karir, reputasi yang dimiliki perusahaan, solidaritas tim kerja, sumber daya yang memadai, kebebasan berpendapat, dan penyampaian visi yang jelas. Indikator untuk work engagement menurut Schaufeli \& Bakker (2004) antara lain vigor, dedication, dan absorption.

\section{Hubungan antar Variabel}

Crawford et al. (2010) menggunakan meta-analysis untuk mengekplorasi pengaruh job demand pada work engagement. Penelitian ini membagi job demand dalam dua tipe yaitu hindrance demand dan challenge demand dan ditemukan bahwa hindrance demand berpengaruh signifikan negatif pada work engagement namun challenge demand mampu berpengaruh signfikan positif terhadap work engagement.

Salmela-aro \& Upadyaya (2018) mengukur work engagement dengan menggunakan indikator yang terdiri atas dedication, vigor dan absorption, adapun empat pernyataan dari penelitian tersebut dengan indikator work demands, interpersonal demands dan multi-cultural demands menjadi alat ukur job demand. Penelitian ini membuktikan job demand dengan signifikan memengaruhi negatif work engagment. Sejalan dengan penelitian tersebut terdapat penelitian dari Bimantari (2015) menjelaskan pengaruh dari job demand ke work engagement terbukit signifikan negatif. Kemudian, Nahrgang et al. (2011) memberikan penjelasan terdapat pengaruh yang signifikan negatif dari job demand ke work engagement. Di sisi lain, merujuk pada penelitian Saputra (2019) pengaruh yang signifikan dan positif ditemukan dari job demand ke work engagement.

\section{H1: Diduga terdapat pengaruh negatif job demand pada work engagement.}

Yener \& Coskun (2013) mengeksplorasi sejauh mana job demand mampu menyebabkan burnout pada pekerja di Kota Istanbul. Indikator dari burnout diantaranya yaitu depersonalization, emotional exhaustion dan personal accomplishment. Selanjutnya, role conflict, work overload dan role ambiguity menjadi indikator job demand. Penelitian ini menujukkan job demand berpengaruh positif pada burnout dengan signifikan.

Kim \& Wang (2018) secara khusus menganalisis efek langsung, tidak langsung dan moderat dari JD$\mathrm{R}$ model pada burnout dengan menggunakan karyawan bagian pelayanan perusahaan publik sebagai objek penelitian. Penelitian ini mengungkapkan job demand dengan signifikan dan kuat memengaruhi burnout secara positif. Indikator job demand meliputi role ambiguity, customer contact dan workload. Kemudian untuk indikator burnout yang digunakan meliputi saya merasakan kelelahan secara emosional dengan pekerjaan saya, saya merasakan lelah setelah bekerja seharian, saya kurang berminat pada pekerjaan saya, dan saya memiliki keraguan pekerjaan saya bermanfaat bagi saya. 
Oktarina (2017) mendapati job demand mampu memengaruhi positif burnout dengan signifikan. Adapun Crawford et al. (2010) mampu menjelaskan pangaruh yang signifikan serta positif dari job demand ke burnout. Demikian pula dengan Salmela-aro \& Upadyaya (2018) mampu memberikan penjelasan job demand sebagai predictor yang kuat memengaruhi secara positif burnout.

H2: Diduga terdapat pengaruh positif job demand pada burnout.

Villavicencio-ayub et al. (2015) melakukan penelitian pada organisasi di Kota Meksiko dan berhasil membuktikan burnout sebagai variabel independen mampu memengaruhi work engagement dengan hubungan siginifikan negatif. Indikator work engagement yang digunakan adalah vigor, absorption dan dedication, serta indikator burnout penelitian ini yaitu emotional exhaustion, depersonalization dan personal accomplishment.

Christianty \& Widhianingtanti (2016) dengan menggunakan uji korelasi berhasil menjelaskan burnout yang memiliki hubungan signifikan negatif dengan work engagement pada accounting staff PT BPR Restu Grup. Kelelahan fisik, kelelahan mental serta kelelahan emosional adalah indikator yang digunakan untuk mengukur burnout karyawan. Adapun work engagement dengan menggunakan indikator employee feelings dan employee behavior. Penelitian tersebut mendapat dukungan dari penelitian Broeck et al. (2017) dengan membuktikan adanya korelasi negatif diantara burnout dengan work engagement. Crawford et al. (2010) memberikan penguatan hasil signifikan serta negatif yang ditemukan dalam hubungan burnout dengan work engagement. Demikian pula dengan Cole et al. (2012) menemukan adanya hubungan negatif dan signifikan diantara burnout dengan work engagement.

H3: Diduga terdapat pengaruh negatif burnout pada work engagement.

Burnout yang karyawan alami diakibatkan oleh job demand yang tidak dikelola dangan baik dapat mempengaruhi tingkat work engagement karyawan sebagaimana dengan Bakker et al. (2014) yang menjelaskan mengenai perkembangan teori Job Demand Resources of Occupational Well-Being di mana burnout digambarkan memediasi pengaruh job demand pada work engagement.

H4: Diduga burnout memediasi pengaruh job demand pada work engagement

\section{METODE PENELITIAN}

Penelitian ini merupakan penelitian kausal. Populasi dari penelitian ini adalah karyawan Consumer Collection and Remedial Unit Bank Tabungan Negara Kantor Cabang Surabaya sebesar 32 karyawan. Teknik sampling yang digunakan adalah sensus artinya total populasi digunakan sebagai sampel penelitian (Cooper \& Schindler, 2014) sehingga ukuran sampel penelitian ini yaitu 32 responden. Adapun variabel penelitian ini antara lain: job demand $(\mathrm{X})$, burnout $(\mathrm{Z})$, dan work engagement $(\mathrm{Y})$. Penghimpunan data melalui cara observasi dan kuesioner.

Penelitian ini dengan menggunakan Utrecht Work Engagement Scale (Schaufeli \& Bakker, 2004) untuk mengukur work engagement, Maslach Burnout Inventory (Maslach \& Leiter, 2016) untuk mengukur burnout, serta Job Demand Scale (Yener \& Coskun, 2013) digunakan untuk mengukur job demand. Likert scale dipilih sebagai skala pengukuran dengan rincian: skala 1 dimaknai sebagai sangat tidak setuju sampai dengan skala 5 yang memiliki arti sangat setuju (Sekaran \& Bougie, 2014). Sumber data yang dimanfaatkan penelitian ini adalah primary data dan secondary data. Analisis data menggunakan Structural Equation Model Partial Least Square (SEM-PLS) serta memanfaatkan aplikasi SmartPLS 3.0.

\section{HASIL DAN PEMBAHASAN}

Tabel 1 menyajikan secara rinci hasil karaktersitik responden yang menjadi partisipan penelitian ini. Karaktersistik responden kategori jenis kelamin didapati sebagian besar laki-laki sebesar $81.3 \%$. 
Karakteristik responden didasari oleh usia mayoritas merupakan responden dengan rentang usia 21-30 tahun sebesar 78,2\%. Status responden lebih banyak responden lajang dengan presentase $59,4 \%$. Pendidikan responden didominasi responden dengan pendidikan SLTA/sederajat sebesar $53,1 \%$. Adapun masa kerja responden selama 11-20 tahun mendominasi dengan presentase 12,6\%.

\section{KARAKTERISTIK RESPONDEN}

\begin{tabular}{llc}
\hline Karakteristik & \multicolumn{1}{c}{ Kategori } & Presentase \\
\hline \multirow{2}{*}{ Jenis kelamin } & Laki-laki & $81,3 \%$ \\
& Perempuan & $18,8 \%$ \\
& $21-30$ tahun & $78,2 \%$ \\
\multirow{2}{*}{ Usia } & $31-40$ tahun & $9,4 \%$ \\
& $41-50$ tahun & $9,3 \%$ \\
\multirow{2}{*}{ Status } & 51-60 tahun & $3,1 \%$ \\
& Lajang & $59,4 \%$ \\
Pendidikan & Menikah & $40,6 \%$ \\
& Strata satu & $46,9 \%$ \\
\multirow{3}{*}{ Masa kerja } & SLTA/sederajat & $53,1 \%$ \\
& 1-10 tahun & $8,4 \%$ \\
& 11-20 tahun & $12,6 \%$ \\
Sumber: Output & $3,1 \%$ \\
\hline
\end{tabular}

Sumber: Output SPSS, data diolah.

Hasil analisis statistik deskriptif dengan menggunakan nilai mean dalam penelitian ini menemukan bahwa work engagement karyawan masuk kategori tinggi tercermin dari nilai rata-rata 4,27. Adapun burnout karyawan dikategorikan tinggi dengan skor mean sebesar 3,83. Selanjutnya, job demand karyawan termasuk pada kategori tinggi didasari nilai rata-rata 4,14.

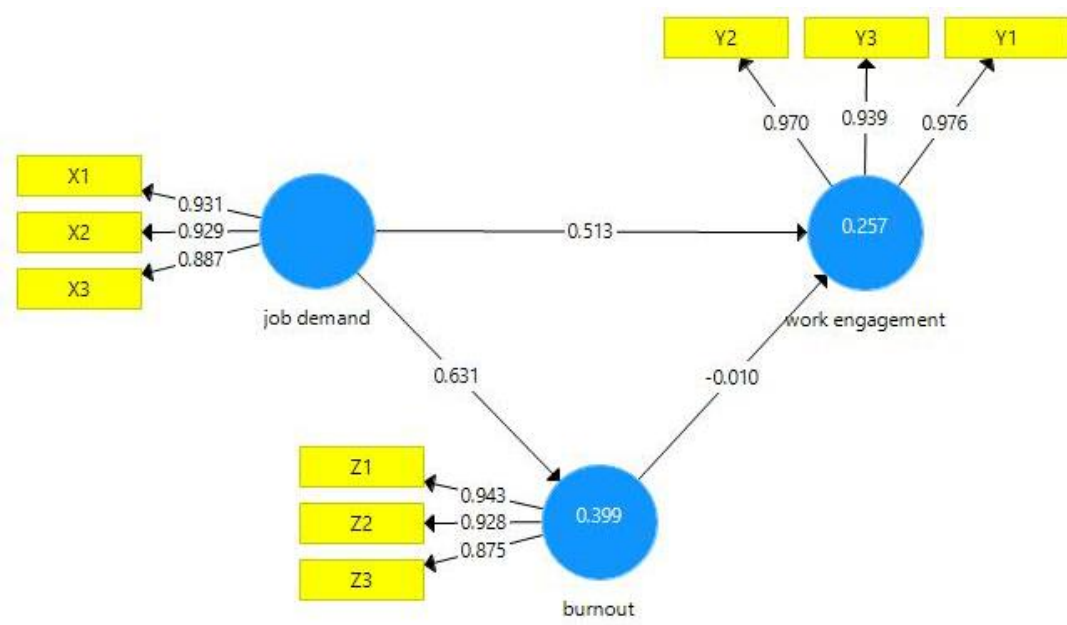

Sumber: Output SmartPLS

GAMBAR 1. PENGUJIAN MEASUREMENT MODEL

Pada gambar 1, outer loading dari job demand, burnout dan work engagement di atas 0,50 sehingga dapat diketahui seluruh konstruk indikator yang terdapat di penelitian ini terbukti valid (Ghozali, 2008).

Tabel 2 menunjukkan work engagement, burnout dan job demand memiliki composite reliability di atas 0,70 artinya didapati seluruh variabel penelitian ini dengan reliabilitas yang baik (Ghozali, 2008). Adapun cronbach's alpha pada tabel 2 menunjukkan semua konstruk di atas 0,60 artinya model variabel penelitian ini memiliki reliabilitas yang kuat (Ghozali, 2008). Selanjutnya, pada tabel 2 diketahui $R$-Square variabel work engagement sebesar 0,206 dan $R$-Square varibel burnout yaitu 
0,379 sehingga dapat dimaknai bahwa besarnya pengaruh job demand terhadap work engagement adalah 20,6\%, serta besarnya pengaruh job demand pada burnout sebesar 37,9\%, sedangkan variabel yang lainya dapat memengaruhi sisanya.

Tabel 2.

COMPOSITE RELIABILITY, CRONBACH'S ALPHA DAN R-SQUARE VARIABEL

\begin{tabular}{|c|c|c|c|}
\hline Variabel & Composite Reliability & Cronbach's Alpha & R-Square \\
\hline WE & 0,974 & 0,960 & 0,206 \\
\hline BU & 0,940 & 0,903 & 0,379 \\
\hline JD & 0,940 & 0,904 & \\
\hline
\end{tabular}

Sumber: Output SPSS, data diolah.

Tabel 3.

HASIL PATH COEFFICIENTS DAN INDIRECT EFFECT

\begin{tabular}{lcccc}
\hline \multicolumn{1}{c}{ Hubungan antar Variabel } & $\begin{array}{c}\text { Original } \\
\text { Statistic }\end{array}$ & T-Statistic & $\begin{array}{c}\text { Cut of } \\
\text { Value }\end{array}$ & Keterangan \\
\hline Job demand $\rightarrow$ Work engagement & 0,513 & 4,757 & & Sig + \\
Job demand $\rightarrow$ Burnout & 0,631 & 6,933 & $\geq 1,96$ & Sig + \\
Burnout $\rightarrow$ Work engagement & $-0,010$ & 0,056 & & Non-Sig - \\
Job demand $\rightarrow$ Burnout $\rightarrow$ Work engagement & $-0,007$ & 0,053 & & Non-Sig - \\
\hline
\end{tabular}

Sumber: Output SPSS, data diolah.

Merujuk tabel 3, $t$-statistic dari pengaruh job demand kepada work engagement yaitu 4,757 $\geq 1,96$ dan nilai coefficient estimate positif sebesar 0,513 , maknanya terdapat pengaruh yang signifikan serta positif job demand ke work engagement. Besar skor t-statistic hubungan job demand terhadap burnout adalah $6,933 \geq 1,96$ serta skor coefficient estimate bernilai positif sebesar 0,631 , artinya terdapat pengaruh signifikan positif job demand pada burnout. Hasil t-statistic burnout pada work engagement menunjukkan $0,056 \leq 1,96$ dengan coefficient estimate bernilai negatif - 0,01 , oleh karena itu diketahui tidak didapati pengaruh dari burnout ke work engagement yang signifikan. Adapun hasil dari $t$ statistic pengaruh dari job demand ke work engagement melalui burnout adalah $0,053 \leq 1,96$ serta pula nilai coefficient estimate negatif $-0,007$, sehingga dapat dimaknai bahwa burnout tidak mampu menjadi mediator pengaruh dari job demand untuk work engagement.

\section{Pengaruh Job Demand terhadap Work Engagement}

Hasil pengujian mendapati job demand memiliki pengaruh ke work engagement secara signifikan positif. Artinya, jika tingkat job demand karyawan meningkat maka level work engagement karyawan dapat turut meningkat sejalan dengan peningkatan job demand.

Hasil dari penelitian ini adalah H1 ditolak, diperkuat penelitian Saputra (2019) dengan membuktikan job demand berpengaruh positif serta signifikan pada work engagement staf Badan Keuangan Daerah Boyolali. Crawford et al. (2010) menambahkan job demand terbagi atas dua tipe yaitu hindrance demand dan challenge demand serta membuktikan bahwa challenge demand dapat berpengaruh signifikan positif terhadap work engagement, karena tantangan pekerjaan dapat meningkatkan emosi positif dan tanggung jawab karyawan terhadap tugas.

Berdasarkan hasil pengamatan, karyawan Consumer Collection and Remedial Unit memiliki target dan tujuan yang jelas sehingga karyawan akan lebih mudah dalam memfokuskan pekerjaan mereka, akibatnya karyawan akan lebih aktif melibatkan diri dalam pekerjaan dan saling mendukung sesama kolega.

Hasil wawancara bersama karyawan bagian collective diperoleh keterangan bahwa tuntutan pekerjaan karyawan Consumer Collection and Remedial Unit sangat tinggi baik di kantor maupun di lapangan serta tantangan terberat adalah debitur, karena dalam melakukan pembinaan dan penagihan karyawan diharuskan menggunakan kemampuan dan kreativitas untuk mendorong debitur membayar angsuran 
dan skill utama karyawan adalah komunikasi. Team leader menambahkan terdapat faktor lainya yang mampu mendorong tumbuhnya tingkat work engagement yaitu job control di mana karyawan memiliki peran dalam mengambil keputusan dan memiliki kesempatan untuk berpendapat terkait penyelesaian masalah.

Job demand terbukti berpengaruh pada work engagement dengan signifikan positif. Berdasarkan hasil penelitian dan keterangan dari karyawan Consumer Colletion and Remedial Unit dapat diketahui bahwa challenge demand dapat meningkatkan semangat dan keterlibatan karyawan di dalam pekerjaan sehingga work engagement dapat meningkat. Keterlibatan karyawan dalam pekerjaan dapat tercermin dari peran karyawan dalam mengambil keputusan dan dukungan diantara karyawan.

\section{Pengaruh Job Demand terhadap Burnout}

Hasil dari pengujian menunjukkan bahwa job demand dapat memberikan pengaruh signifikan positif pada burnout. Oleh karena itu, jika tingkat job demand meningkat maka level burnout karyawan dapat turut meningkat. Dengan demikian, H2 diterima.

Penelitian ini dapat mendukung penelitian Kim \& Wang (2018) yang menemukan job demand karyawan perusahaan pelayanan publik signifikan positif berpengaruh pada burnout. Merujuk penelitian Santoso \& Hartono (2017) menunjukkan job demand manajer proyek di Indonesia berpengaruh signifikan dan berhubungan positif pada burnout yang manajer proyek rasakan.

Uji statistik deskriptif menunjukkan skor rata-rata job demand lebih tinggi dari skor rata-rata burnout. Skor rata-rata indikator tertinggi job demand yaitu work overload, hal ini mengindikasikan beban kerja yang dimiliki karyawan kurang merata dan melebihi kapasitas karyawan dalam menyelesaikan tugas, sementara itu indikator cynism dari variabel burnout adalah yang tertinggi artinya karyawan Consumer Collection and Remedial Unit merasa kurang memiliki kebanggaan terhadap pekerjaan yang mereka lakukan sebagai debt collector.

Wawancara yang dilakukan bersama pimpinan Consumer Collection and Remedial Unit menjelaskan bahwa beban kerja karyawan akan serasa lebih berat saat menjelang akhir bulan karena tambahan beban time pressure. Selain itu, sebagian besar karyawan memiliki tanggung jawab baik di kantor maupun di lapangan, hambatan-hambatan yang ditemui oleh karyawan saat bertugas lapangan menyebabkan energi dan waktu mereka terkuras lebih banyak serta akan diperparah jika karyawan terlibat adu pendapat dengan debitur.

Berdasarkan hasil pengamatan sebagian besar karyawan di Consumer Collection and Remedial Unit merupakan pegawai outsourcing yang rentan mengalami kesenjangan dengan nilai-nilai Bank Tabungan Negara. Keterangan dari karyawan bagian administrasi bahwa karyawan outsourcing sering kali mendapat perlakuan berbeda di dalam komunitas serta tidak memiliki kesempatan untuk jenjang karir menyebabkan rasa rendah diri dan semangat berkurang.

Penelitian ini membuktikan job demand karyawan Consumer Collection and Remedial Unit yang tinggi menyebakan burnout yang dirasakan karyawan meningkat. Oleh karena itu, ketersediaan job resources seperti dukungan sosial dapat membantu mengurangi dampak burnout (Elst et al., 2016).

\section{Pengaruh Burnout terhadap Work Engagement}

Hasil analisis dan pengujian membuktikan burnout secara signifkan tidak memiliki efek pada work engagement, maknanya work engagement karyawan tidak terpengaruh oleh level burnout yang dirasakan oleh karyawan. Dengan demikian, H3 ditolak.

Hasil penelitian ini diperkuat oleh penelitian Hikmatullah (2016) bahwa burnout dengan employee engagement tidak ada hubungan yang signifikan. Maricuțoiu et al. (2017) pula menemukan bahwa burnout secara signifikan tidak memiliki hubungan dengan work engagement. 
Berdasarkan uji statistik deskriptif skor mean burnout dan work engagement tergolong tinggi, namun skor rata-rata work engagement lebih tinggi dari burnout. Indikator tertinggi variabel work engagement adala vigor artinya karyawan memiliki energi fisik yang sangat banyak sehingga dapat digunakan untuk menyelesaikan tugas baik di dalam kantor maupun di lapangan.

Berdasarkan hasil analisis karakteristik responden dapat diketahui sebagian besar karyawan berjenis kelamin laki-laki, sebagaimana penuturan dari karyawan bagian asistant field collector bahwa pekerjaan di lapangan lebih cocok untuk laki-laki dibandingkan perempuan karena memiliki risiko tinggi serta lebih banyak hambatan, tidak jarang energi fisiologis maupun psikologis dapat terkuras hanya untuk kunjungan lapangan.

\section{Pengaruh Job Demand terhadap Work Engagement melalui Burnout}

Hasil pengujian membuktikan bahwa t-statistic lebih rendah dari cut of value, sehingga dapat diartikan bahwa burnout tidak dapat atau tidak memiliki peran mediasi pengaruh dari job demand ke work engagement, dengan demikian $\mathrm{H} 4$ ditolak.

Apabila dikaitkan dengan penelitian yang dilakukan di Consumer Collection and Remedial Unit Bank Tabungan Negara Cabang Surabaya berdasarkan keterangan dari karyawan bagian desk call terdapat beberapa faktor yang dapat meningkatkan work engagement seperti hubungan dan komunikasi yang baik dengan atasan, dukungan organisasi, dan dukungan dari rekan kerja. Hal tersebut sejalan dengan penelitian Lee et al. (2019) yang menyatakan bahwa job resources memoderasi pengaruh job demand pada work engagement.

Hasil dari penelitian ini memberikan informasi bahwa variabel burnout tidak dapat menjadi variabel mediasi antara job demand dengan work engagement, karena ada tidaknya burnout variabel job demand telah bepengaruh positif ke work engagement dengan siginifkan serta terdapat variabel lain yang lebih dibutuhkan karyawan untuk dapat meningkatkan work engagement.

\section{KESIMPULAN}

Merujuk hasil uji serta pembahasan yang dijabarkan sebelumnya maka diketahui job demand berpengaruh pada work engagement dan burnout dengan signifikan positif, burnout tidak dapat memperlemah work engagement serta burnout tidak mampu menjadi mediator pengaruh job demand terhadap work engagement. Implikasi utama yang didasari oleh penelitian ini diantaranya optimalisai tuntutan pekerjaan serta sumber daya pekerjaan. Optimaslisai tuntutan pekerjaan dapat dilakukan diantaranya mengurangi ambiguitas dan konflik peran dengan cara mengisi jabatan yang kosong, dan menambah karyawan agar beban kerja dapat terbagi dengan rata dan tidak tumpang tindih diantara karyawan. Sumber daya pekerjaan dapat ditingkatkan diantaranya dengan pemberian financial reward sesuai tingkat pencapaian target, menambah fasilitas kendaraan untuk kunjungan lapangan, serta meningkatkan keterlibatan karyawan dalam mengambil keputusan dan mengutarakan pendapat. Penelitian ini terbatas pada tiga variabel yaitu job demand, burnout dan work engagement, untuk itu penelitian selanjutnya diharapkan dapat memperluas variabel diantaranya job resources, job stress dan work-home interaction serta melebarkan objek penelitian terutama di industri perbankan.

\section{DAFTAR PUSTAKA}

Bakker, A. B., \& Demerouti, E. (2016). Job Demands-Resources Theory: Taking Stock and Looking Forward. Journal of Occupational Health Psychology, 22(3), 273-285. https://doi.org/http://dx.doi.org/10.1037/ocp0000056

Bakker, A. B., Demerouti, E., \& Sanz-vergel, A. I. (2014). Burnout and Work Engagement : The JD R Approach. The Annual Review of Organizational Psychology and Organizational Behavior, 1, 389-411. https://doi.org/10.1146/annurev-orgpsych-031413-091235

Bakker, A. B., Demerouti, E., \& Verbeke, W. (2004). Using The Job Demands-Resources Model to 
Predict Burnout and Performance. Human Resource Management, 43(1), 83-104. https://doi.org/10.1002/hrm.20004

Bimantari, P. (2015). Pengaruh Job Demands, Personal Resources, dan Jenis kelamin Terhadap Work Engagement. Diakses pada 20 Februari 2020, dikutip dari http://repository.uinjkt.ac.id/dspace/handle/123456789/33440

Broeck, A. Van Den, Elst, T. Vander, Baillien, E., Sercu, M., Schouteden, M., Witte, H. De, \& Godderis, L. (2017). Job Demands, Job Resources, Burnout, Work Engagement, and Their Reationship: An Analysis Across Sectors. Journal of Occupational and Environmental Medicine, 59(4), 369-376. https://doi.org/10.1097/JOM.0000000000000964

Cahyani, W. (2019). Peran Dukungan Sosial Terhadap Stress Kerja Sebagai Peningkatan Kinerja Karyawan. Jurnal Ilmu Manajemen, 7(3), 868-876. Diakses pada 15 Februari 2020, dikutip dari https://jurnalmahasiswa.unesa.ac.id/index.php/jim/article/view/29331

Christianty, T. O. V., \& Widhianingtanti, L. T. (2016). Burnout Ditinjau dari Employee Engagement pada Karyawan. Psikodimensia, 15(2), 351-373. Diakses pada 16 Februari 2020, dikutip dari http://103.243.177.137/index.php/psi/article/download/996/658

Coetzer, C., \& Rothmann, S. (2007). Job Demands, Job Resources and Work Engagement of Employees in A Manufacturing Organisation. Southern African Business Review, 11(3), 17-32. Diakses pada $15 \quad$ Februari 2020, dikutip dari https://journals.co.za/content/sabr/11/3/EJC92864?crawler=true\&mimetype=application/pdf

Cole, M. S., Walter, F., Bedeian, A. G., Boyle, E. H. O., Cole, M. S., \& Walter, F. (2012). Job Burnout and Employee Engagement: A Meta-Analytic Examination of Construct Proliferation. Journal of Management, 38(5), 1550-1581. https://doi.org/10.1177/0149206311415252

Cooper, D. R., \& Schindler, P. S. (2014). Business Research Methods (Twelfth Ed). New York: Mc Graw-Hill/Irwin.

Crawford, E. R., Lepine, J. A., \& Rich, B. L. (2010). Linking Job Demands and Resources to Employee Engagement and Burnout: A Theoretical Extension and Meta-Analytic Test. Journal of Applied Psychology, 95(5), 834-848. https://doi.org/10.1037/a0019364

Elst, T. Vander, Cavents, C., Daneels, K., Johannik, K., Baillien, E., Broeck, A. Van Den, \& Godderis, L. (2016). Job Demands-Resources Predicting Burnout and Work Engagement among Belgian Home Healthcare Nurses: A Cross-Sectional Study. Nursing Outlook, 64(6), 542-556. https://doi.org/10.1016/j.outlook.2016.06.004

Fazlurrahman, H. (2018). Change Management in Islam Perspective. Jurnal Ilmiah Bidang Akuntansi, 15(1), 54-60. Diakses pada 14 Februari 2020, dikutip dari http://riset.unisma.ac.id/index.php/jema

Ghozali, I. (2008). Structural Equation Modelling: Metode Alternatif Dengan Partial Leat Square. Semarang: Badan Penerbit Universitas Diponegoro.

Hikmatullah, F. (2016). Hubungan Employee Engagement dan Burnout Pada Karyawan Divisi IT. Jurnal Ilmiah Psikologi, 9(1), 100-108. Diakses pada 16 Februari 2020, dikutip dari https://ejournal.gunadarma.ac.id/index.php/psiko/article/view/1548/1307

Hurrel, J. J., Murphy, L. R., \& Cooper, S. L. (1988). Occupational Stress: Issue and Development in Research. London: Taylor \& Francis Ltd. 
Kim, S., \& Wang, J. (2018). The Role of Job Demands - Resources ( JDR ) between Service Workers' Emotional Labor and Burnout: New Directions for Labor Policy at Local Government. Journal of Enviromental Research and Public Health, 15(12), 2894. https://doi.org/10.3390/ijerph15122894

Kristensen, T. S., Borritz, M., Villadsen, E., \& Christensen, K. B. (2005). The Copenhagen Burnout Inventory: A New Tool For The Assessment of Burnout. Journal of Work, Health and Organization, 19(3), 192-207. https://doi.org/http://dx.doi.org/10.1080/02678370500297720

Lee, A., Kim, H., Faulkner, M., Gerstenblatt, P., \& Travis, D. J. (2019). Work Engagement among Child - Care Providers: An Application of The Job Demands - Resources Model. Child \& Youth Care Forum, 48(1), 77-91. https://doi.org/10.1007/s10566-018-9473-y

Maricuțoiu, L. P., Sulea, C., \& Iancu, A. (2017). Work Engagement or Burnout : Which Comes First ? A Meta-Analysis of Longitudinal Evidence. Burnout Research, 5, 35-43. https://doi.org/10.1016/j.burn.2017.05.001

Martin. (2017). Industry 4.0: Definition, Design Principles, Challenges, and the Future of Employment. Diakses pada 20 Januari 2020, diakses dari https://www.cleverism.com/industry$4-0 /$

Maslach, C., \& Leiter, M. P. (2016). Understanding The Burnout Experience : Recent Research and its Implications for Psychiatry. Journal of World Psychiatry, 15(2), 103-111.

Moeller, J., Ivcevic, Z., White, A. E., Menges, J. I., \& Brackett, M. A. (2017). Highly Engaged but Burned Out: Intra-Individual Profiles in The US Workforce. Journal of Career Development International, 23(1), 86-105. https://doi.org/10.1108/CDI-12-2016-0215

Montgomery, A., Spânu, F., Adriana, B., \& Panagopoulou, E. (2015). Job Demands, Burnout, and Engagement among Nurses: A Multi-Level Analysis of Orcab Data Investigating The Moderating Effect of Teamwork. Burnout Research, 2, 71-79. https://doi.org/10.1016/j.burn.2015.06.001

Nahrgang, J. D., Morgeson, F. P., \& Hofmann, D. A. (2011). Safety at Work: A Meta-Analytic Investigation of the Link Between Job Demands, Job Resources, Burnout, Engagement, and Safety Outcomes. Journal of Applied Psychology, 96(1), 71-94. https://doi.org/10.1037/a0021484

Oktarina, A. N. (2017). Pengaruh Job Demand Pada Burnout dengan Job Resource dan Personal Resource sebagai Pemoderasi : Studi pada PT Kusumaputra Santosa Karanganyar. Prosiding Seminar Pendidikan Ekonomi dan Bisnis. Diakses pada 17 Februari 2020, dikutip dari http://www.jurnal.fkip.uns.ac.id/index.php/snpe/article/viewFile/10673/8350

Perrin, T. (2013). Working Today: Understanding What Drives Employee Engagement Towers Perrin Annual Report. Diakses pada 15 Februari 2020, dikutip dari www.towerperrin.com

Ramadhani, Y. N., \& Hadi, C. (2018). Pengaruh Job Demands-Resources Terhadap Employee Engagement Pada Staff Account Officer PT. X Wilayah Jombang. Jurnal Psikologi Industri dan Organisasi, 7, 1-15. Diakses pada 20 Februari 2020, dikutip dari http://url.unair.ac.id/cf758369

Salmela-aro, K., \& Upadyaya, K. (2018). Role of Demands-Resources in Work Engagement and Burnout in Different Career Stages. Journal of Vocational Behavior, 108, 190-200. https://doi.org/10.1016/j.jvb.2018.08.002 
Santoso, P. N., \& Hartono, B. (2017). Pengaruh Job Demand-Resources Terhadap Burnout Pada Manajer Proyek Indonesia. Seminar Nasional Teknik Industri Universitas Gajah Mada 2017 (pp. 82-92). Yogyakarta: Program Studi Teknik Industri Departemen Teknik Mesin dan Industri.

Saputra, A. (2019). Analisis Pengaruh Job Demand, Job Resources dan Personal Resources Terhadap Work Engagement (Studi Pada Badan Keuangan Daerah Kabupaten Boyolali). Diakses pada 10 Maret 2020, dikutip dari http://eprints.ums.ac.id/70900/

Schaufeli, W. B., \& Bakker, A. B. (2004). Job Demands, Job Resources, and Their Relationship with Burnout and Engagement: A Multi-Sample Study. Journal of Organizational Behavior, 25, 293-315. https://doi.org/10.1002/job.248 Job

Schaufeli, W., \& Bakker, A. (2004). Utrecht Work Engagement Scale: Preliminary Manual. Occupational Health Psychology Unit. Utrecht: Utrecht University.

Schaufeli, W., Truss, C., Alfes, K., Delbridge, R., Shantz, A., \& Soane, E. (2013). What Is Engagement? In Employee Engagement In Theory And Practice (pp. 1-37). London: Routledge.

Sekaran, U., \& Bougie, R. (2014). Metode Penelitian Untuk Bisnis. Hoboken: Jhon Wiley \& Sons Inc.

Upadyaya, K., Ph, D., Vartiainen, M., Ph, D., \& D, K. S. P. (2016). From Job Demands and Resources to Work Engagement, Burnout, Life Satisfaction Depressive Symptoms and Occupational Health. Burnout Research, 3(4), 101-108. https://doi.org/10.1016/j.burn.2016.10.001

Villavicencio-ayub, E., Jurado-cárdenas, S., \& Valencia-cruz, A. (2015). Work Engagement and Occupational Burnout: Its Relation to Organizational Socialization and Psychological Resilience. Journal of Behavior, Health and Social Issues, 6(2), 45-55. https://doi.org/10.5460/jbhsi.v6.2.47026

Yener, M., \& Coskun, O. (2013). Using Job Resources and Job Demands in Predicting Burnout. International Strategic Management Conference (pp. 869-876). Elsevier Ltd. 